\title{
Development of Russian Economy in Conditions of Globalization and Investment Policy
}

Toumashev A.R.

Toumasheva M.V.

Valeev E.R.

Miasnikov D.A.

Kazan Federal University, Institute of Management, Economics and Finance, Kazan, 420008, Russia

\section{Doi:10.5901/mjss.2015.v6n3p700}

\section{Abstract}

Theoretical issues of Russian economy development in the context of globalization, internal and external factors, forming tendencies of structural changes of national production are considered in the article. The situation on the Russian market of exported goods, and its impact on the financial system of Russia are considered. Conditions for investment business are analyzed, the role of state finance, taxation and monetary policies on the performance of business in Russia are explored. A comparative analysis of investment conditions in Russia and in Western developed countries is made. Possible changes in macroeconomic policies, aimed at improving the conditions for investments in Russia, are determined.

Keywords: Economic development, Russian economy, investment climate (conditions), financial policy, investment policy.

\section{Introduction}

The character of development of Russian economy under the conditions of globalization, its entrance to WTO are mainly determined not only by internal, but external factors and ideology of world market [1][2], realities of globalization [3][4][7], its institutions and driving forces [11]. As a result of entering the world economy as a supplier of energy and raw materials and the local center of consumption, the structure of national production has changed in Russia, the role of hydrocarbon export in the formation of budget revenues has increased. Even the innovative activity, as the practice of major Russian regions shows, jumped into the sphere of Oil and Gas production [5]. At the same time, business conditions in primary industries are unfriendly, due to the lack of effective state investment policy.

\section{Theory}

Conditions of business in Russia mainly depend on the situation prevailing in the markets of goods exported by the country, hydrocarbons in the first place. This directly affects the condition of state and private finance and determines the state of the aggregate domestic demand. [6] Oil, rising in price since 2000 , has forced the countries, large corporations and private entrepreneurs to direct huge resources into the development of renewable energy technologies, energetics, alternative to hydrocarbon, and the development of new technologies for the extraction of oil and gas deposits, previously not considered as suitable for use, shale gas and oil in the first place. Despite the high cost of technology and the significant environmental damage, concomitant extraction of raw materials from the shale, it can be stated that the increase in production from shale deposits in the US up to 8.5 million. barrels per day, which is 1.6 times more than three years ago; this has allowed them to become independent from the external supply of hydrocarbons, to lower domestic oil prices (WTI), to create conditions for relative stability of the internal market and begin to deal with challenges of reindustrialization of the country on a new technological basis.

Further development of oil and gas extraction by the United States is not the only reason to increase the supply of hydrocarbons to the world market. Reduced intensity of confrontation between the US and Iran opened prospects for increasing exports of crude oil. Oil supplies from Libya and Asian countries increased significantly, new fields of qualitative oil are discovered. With the reduction of the volume of consumption of raw materials under conditions of global crisis there have formed conditions for reduction of world oil prices, which worsens the position of oil and gas exporters.

Dynamics of quarterly GDP growth rates show that in 2012 the growth rate of Russian economy slowed down. 
GDP growth in early 2012 at an annual rate was 4.9\%, and in November 2012 it dropped to 1.2\%. This happened at the same prices for oil, as in 2007, when the economy showed a steady growth. High oil prices no longer provided the implementation of Prime Minister Dmitry Medvedev's optimistic forecasts on the need and the attainable level of economic growth of 5\%. The head of the Ministry of Economic Development Alexei Ulyukayev, who noted the deteriorating situation, spoke out pessimistic. This forecast was made prior to the exchange of economic sanctions with the West, and the dynamics of Russia's GDP has confirmed his skepticism [6].

Table 1. Russia's GDP at constant prices of 2008 with the exception of seasonal factors (2011-2014, quarterly, bln. Rubles)

\begin{tabular}{|c|c|c|c|}
\hline & GDP current value (in bln.) & GDP growth in the previous quarter,\% & $\begin{array}{c}\text { GDP growth to the corresponding } \\
\text { quarter of previous year, } \%\end{array}$ \\
\hline 2011 - Q1 & 10217,9 & 1,04 & 3,77 \\
\hline 2011 - Q2 & 10317,4 & 0,97 & 3,69 \\
\hline 2011 - Q3 & 10464,9 & 1,43 & 4,66 \\
\hline 2011 - Q4 & 10606,1 & 1,35 & 4,88 \\
\hline 2012 - Q1 & 10763,0 & 0,77 & 4,6 \\
\hline 2012 - Q2 & 10763,0 & 0,7 & 4,32 \\
\hline 2012 - Q3 & 10806,0 & 0,4 & 3,26 \\
\hline 2012 - Q4 & 10807,6 & 0,01 & 1,9 \\
\hline 2013 - Q1 & 10849,0 & 0,38 & 1,51 \\
\hline 2013 - Q2 & 10886,0 & 0,34 & 1,14 \\
\hline 2013 - Q3 & 10915,5 & 0,27 & 1,01 \\
\hline 2013 - Q4 & 10963,3 & 0,44 & 1,44 \\
\hline 2014 - Q1 & 10970,8 & 0,07 & 1,12 \\
\hline 2014 - Q2 & 10997,8 & 0,25 & 1,03 \\
\hline
\end{tabular}

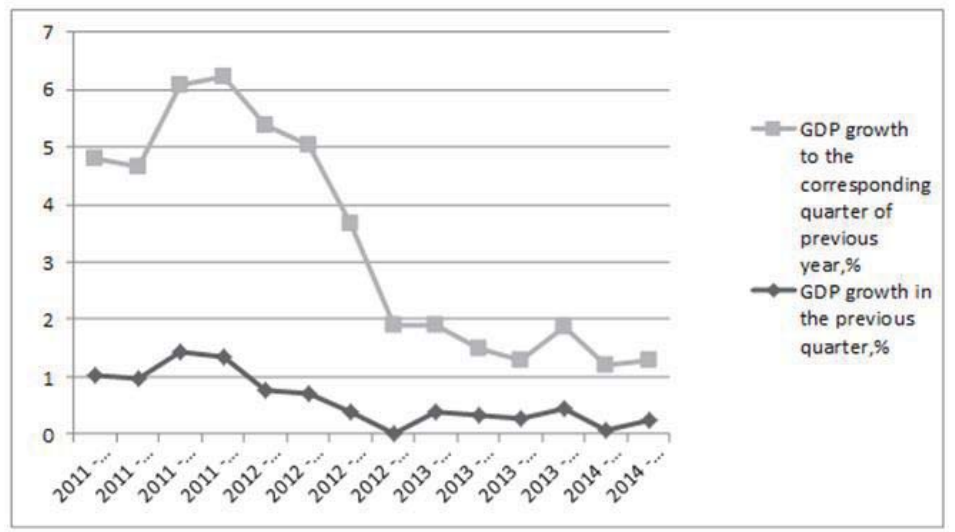

Fig. 1. Dynamics of Russian GDP in constant 2008 prices excluding seasonal factors (2011-2014, quarterly, bln. Rubles)

Western sectorial sanctions imposed in 2014 in relation to Russia, include:

- restrictions on the supply of high-tech products for Russian raw (oil) and defense industries, and also academic institutions;

- restricting access of Russian banks to relatively low foreign financial resources.

The first are aimed at limiting the ability to extract oil from the new fields that require the use of more sophisticated technologies. The US company ExxonMobil closed its ten joint projects after the discovery of the largest oil fields on the Russian shelf of the Kara Sea; this oil exceeds in its quality Siberian Light, comparable with all of the current resource base in Saudi Arabia. The restrictions on lending Russian borrowers for more than 30 days create a shortage of liquidity for financing Russian development projects.

Russian retaliatory sanctions are connected with the introduction of restrictions on food imports from European and American suppliers as not conforming to sanitary and epidemiological requirements.

Collision with Western sanctions generates economic problems that can be solved in two ways. The first is to provide visibility of technological independence in the actual search for new suppliers. Questions of replacing European suppliers of beef and Norwegian fish by Argentinean, Polish apples and Greek fruits by Chinese and Turkish are practically being solved. Changing suppliers is incomparably easier than establishing its own production. 
The second direction of the solution of structural problems is to reduce non-production expenses, focus on available resources and restore production potential. The question of who should organize the investment does not have a unique solution. Government investment in the development of industrial infrastructure, basic industries and transport systems in Russian history of the twentieth century has shown its high efficiency. However, to rely solely on government investment when solving structural problems of modern Russia is impossible for a range of reasons. This pathway is compromised in the mass consciousness targeted by liberal reformatting. In addition, there is a system of property relations; there are social groups, accustomed to new ways of obtaining and distributing their income. Finally, Russian government is currently not characterized by high efficiency and control expenditure of funds. Under these circumstances, provision of structural changes and modernization of the economy are impossible without the participation of private capital in the implementation of national development programs. Unfortunately, the conditions of enterprises' activities outside the circle and distributors and natural monopolists cannot be assessed positively.

The member of board of the Russian Union of Industrialists and Entrepreneurs, the president of "New Commonwealth" and association "Rosagromash" K.A.Babkin prepared an analytical note in October 2013 on the relative efficiency of production of agricultural machinery in Russia and Canada. "Rostselmash", which had purchased the Canadian company «Buhler VERSATILE», was able to supply tractors and other agricultural machines manufactured by this company to the Russian market. It seems rational to localize the production of this equipment in Russia to make it available to consumers. The comparative analysis of the costs and benefits of producing tractors in Russia and Canada showed that, when equal volumes of output and prices, production of of tractors in Canada allows to receive net income of $\$ 16.4$ million US dollars, while production in Russia will bring a loss of 21.7 million dollars. Accordingly, in the first half of 2013 growth of sales of tractors in the first half of 2013 in Canada was 8\%, harvesters - 21\% (in Russia - the decline in both positions - $13 \%$ and $26 \%$ ).

Table 2. Calculation of the commercial feasibility of transferring the production of tractors from Canada to the Russian Federation [8]

\begin{tabular}{|c|c|}
\hline Object of expenditure & Economic effect \\
\hline compensation & $-10,0$ million US dollars \\
\hline Interest on loans & $+14,4$ million US dollars \\
\hline Gas & $-0,7$ million US dollars \\
\hline electric power & $+2,1$ million US dollars \\
\hline freight & $+4,2$ million US dollars \\
\hline protection & $+0,9$ million US dollars \\
\hline accounting & $+1,0$ million US dollars \\
\hline taxes & $+26,1$ million US dollars \\
\hline TOTAL difference (excess costs in production in Russia) & 38,0 million US dollars \\
\hline Net income in Canada & 16,4 million US dollars \\
\hline Net loss in Russia & $\mathbf{- 2 1 , 7}$ million US dollars \\
\hline
\end{tabular}

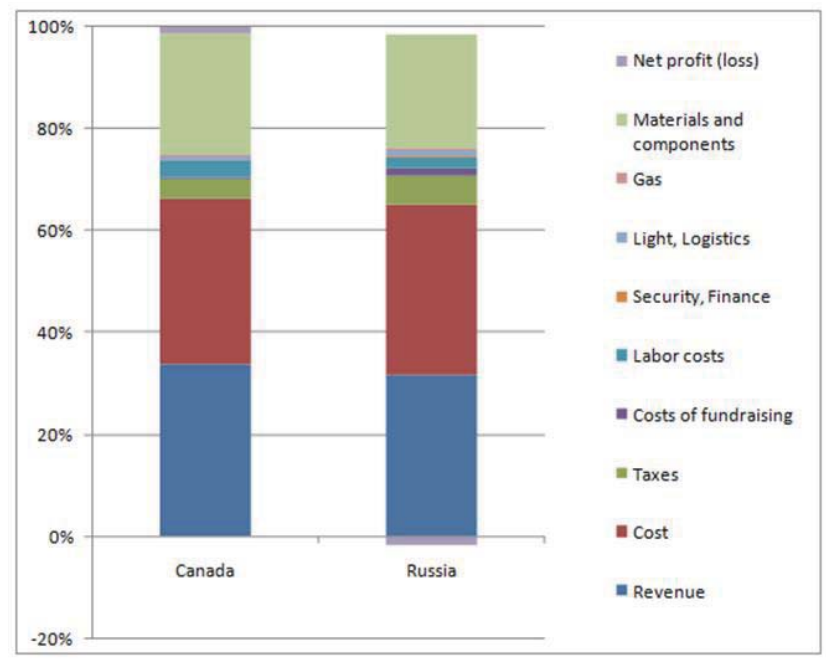

Fig. 2. The structure of the full costs at alternative locations of production. 
Table 3. The structure of the full costs and expected profit at alternative locations of production

\begin{tabular}{|l|c|c|c|}
\hline Revenue, expenditure and net profit & Canada & Russia & change (increase),\% \\
\hline Revenue & $\mathbf{4 0 4 , 5}$ & $\mathbf{4 0 4 , 5}$ & $\mathbf{0}$ \\
\hline Cost & $\mathbf{3 8 8 , 1}$ & $\mathbf{4 2 6 , 2}$ & $\mathbf{1 0}$ \\
\hline Taxes & 47,9 & 74,0 & 57 \\
\hline Costs of fundraising & 3,5 & 17,9 & 411 \\
\hline Labor costs & 38,5 & 28,5 & -26 \\
\hline Security, Finance & 1,0 & 2,9 & 190 \\
\hline Light, Logistics & 9,8 & 16,1 & 64 \\
\hline Gas & 1,2 & 0,5 & -58 \\
\hline Materials and components & 286,3 & 286,3 & 0 \\
\hline Net profit (loss) & 16,4 & $\mathbf{- 2 1 , 7}$ & $\mathbf{- 3 8 , 1 ^ { * }}$ \\
\hline
\end{tabular}

* (Based on alternative losses)

\section{Results}

Transfer of production to Russia reduces labor costs and consumed gas. The major share of costs growth accounts for taxes (1.57 times increase - from 47.9 to 74.0 million dollars) and interest on loans (increase of 5.11 times - from 3.5 to 17.9 million dollars). At higher income tax rate in Canada (35.0\%) compared with the rate used in Russia (20\%), due to a significant amount of tax deductions, effective tax rate in Canada is lower than the Russian and is $16.7 \%$.

The second major factor, which slows down the investment process in Russia, is high cost loans. Annual interest rate on loans in Russia at present is in the range of $11-13 \%$, and for the Canadian production company, the average interest rate in 2012 was 2.3\%. Difficult conditions of activity - the result of demonetization of the economy, the weakness of the banking system, a consequence of the restrictive fiscal and monetary policies.

The Bank of Russia has raised the refinancing rate to $13 \%$ since December $1^{\text {st }} 2008$, making loans virtually unavailable to producers, while Federal Reserve System lowered the refinancing rate from $4.75 \%$ to $1 \%$, and further to $0.25 \%$. As a temporary decrease of the crisis the Bank of Russia lowered the refinancing rate to $7.75 \%$ and then again increased it to $8.25 \%$ [9]. Key rate, actually performing the functions of refinancing rate, is set at $9.5 \%$ on November 5 , 2014. [10]. This decision is justified by the need of reduction of inflationary expectations and risks associated with the decrease of oil prices and sanctions imposed by individual countries on major Russian companies. When the sources of external credits were gone, and the rates on the domestic interbank lending market remained very high (from 8.17\% to $10.05 \%$ on offer and from $8.87 \%$ to $11.35 \%$ on the supply of credit), Russian banks faced a liquidity crisis.

Lack of resources in the market of internal lending is due to accounting policy of the Central Bank and the weakness of the Russian banking system, low level of capitalization of Russian banks, which does not allow them to finance large-scale, long-term investment projects of a strategic nature, which worsens macroeconomic indicators, creates a threat of employment reduction. [8].

Monetization of Russia's GDP at the beginning of 2014 reached only 47\% of GDP (31.404 trillion rubles / 66.755 trillion rubles). This is significantly less than in Western countries (70-120\% of GDP) and moreover countries with emerging markets. At comparable with Russian rates of inflation, coefficient of monetization in China exceeds $200 \%$. It is impossible to deny the rule: the investment process lasts until marginal revenue equals or exceeds the marginal cost. Credit resources price, prevailing in the domestic market, poses a barrier to the most profitable projects needed for the necessary structural changes in the Russian economy.

\section{References}

Manfred B. Steger: Globalism: The New Market Ideology. Rowman \& Littlefield Publishers, 2002. - 195 p.

Weinstein, Michael M. Globalization: What's New? Columbia University Press, 2005. - 279 p.]. External debt of Russian Federation. URL: http://minfin.ru/ru/public_debt/external/

3.Volbert Alexander. The Problem of Optimal Exchange Rate For Central European Countries// Postgraduate Research Programme "Capital markets and Finace in Enlarged Europe", Working Paper Series., № 1/2001.- p.1-30.

Brecher, Jeremy. Globalization from Below: The Power of Solidarity/ Jeremy Brecher, Tim Costello, and Brendan Smith, South End Press, 2002. $-128 \mathrm{p}$.

Gallyamova, D., Toumashev, A., Malaev, V. Influence of globalization on development of the Russian economy//Mediterranean Journal of Social Sciences. - Vol.5, №18, (2014) - pp.133-137.

Lenar N.Safiullin, Gulnara N. Ismagilova, Nail Z. Safiullin. Development of the theory of demand and utility in the conditions of change of 
quality of the goods 2_Topic_Safiullin_Quality.and.Demand_QQE2013_for.Conference.Proceedengs.

De la Dehesa, Guillermo. What Do We Know About Globalization: Issues of Poverty and Income Distribution. Blackwell Publishing., 2007. - $384 \mathrm{p}$.

Fakhrutdinova, E.V.,Kolesnikova, J.S.,Suleimanov, T.D.,Khalikov, A.L. The interrelation of the problems of the youth labour market and the "brain drain". Life Science Journal 2014, 11 (6 SPEC. ISSUE), pp. 473-477

http://www.cbr.ru/pw.aspx?file=/statistics/credit_statistics/refinancing_rates.htm10.http://www.cbr.ru/press/pr.aspx?file=31102014_13302 7dkp2014-10-31T13_15_16.htm

Fischer, Stanley. Globalization and its Challenges, American Economic Review Papers and Proceedings, 2003, Vol. 93(2), pp. 1-30.

I.Sh. Khasanov, Three-sector structure of the national economy of Russia // Asian Social Science, Volume 10, 2014, Pages 217-224.

Khasanov I.Sh. Three-Sector Structure of the National Economy of Russia// Mediterranean Journal of Social Sciences.- Vol.5, No12, (2014)-pp.149 - 153.

Nagimova, A.M., Safiullina, F.R. (2014). Combination of university training with employment among Kazan' students. Sotsiologicheskie Issledovaniya, (4), pp. 121-124.

Tsertseil, J.S. The way of clusters uprising and development in the region (By the example of the petrochemical cluster in the republic of Tatarstan). Mediterranean Journal of Social Sciences, Volume 5, Issue 18 SPEC. ISSUE, 2014, Pages 125-128

Safina, D., Podgornaya, A. (2014). Mobbing as an organizational phenomenon impeding implementation of changes. Mediterranean Journal of Social Sciences, 5 (18 SPEC. ISSUE), pp. 187-192. 